\title{
Community's Perspectives towards Marine Protected Area in Perhentian Marine Park, Malaysia
}

\author{
Gazi Md. Nurul Islam ${ }^{*}$, Tai Shzee Yew ${ }^{2}$, Kusairi Mohd Noh' ${ }^{1}$, Aswani Farhana Mohd Noh ${ }^{1}$ \\ ${ }^{1}$ Institute of Agricultural and Food Policy Studies, Universiti Putra Malaysia, Serdang, Malaysia \\ ${ }^{2}$ Faculty of Economics and Management, Universiti Putra Malaysia, Serdang, Malaysia \\ Email: gazinurul236@gmail.com
}

Received 2 January 2014; revised 19 February 2014; accepted 4 March 2014

Copyright (C) 2014 by authors and Scientific Research Publishing Inc.

This work is licensed under the Creative Commons Attribution International License (CC BY). http://creativecommons.org/licenses/by/4.0/

(c) (i) Open Access

\section{Abstract}

The Perhentian Islands located in the East coast of Peninsular Malaysia. They are well-known for their rich coral reef ecosystems. Marine resources of Malaysia have been overexploited in general due to overfishing and other development activities. Such no-take marine protected areas (MPAs) were established in Malaysia including Perhentian Islands Marine Park to enable overexploited marine resources to recover and to conserve coral reef ecosystems. This paper examines the current level of activities causing damages to the coral reef habitats in the Perhentian MPA. This study used paired comparison method to elicit the perception of the local stakeholders on the activities harmful to the marine habitats. The results of the analysis showed that various respondent groups had similar preference rankings on the harmful activities: littering, discarding fishing equipments, excess fishing and too many divers that cause damage to the habitats in the MPA area. The findings suggest that policy makers should take cognizance of the local stakeholders' concern in planning and designing of marine protected areas in Malaysia.

\section{Keywords}

Marine Protected Areas; Tourism; Overfishing; Preference Ranking; Peninsular Malaysia

\section{Introduction}

Marine Protected Areas (MPAs) have been suggested as an important tool for fishery management particularly in a situation where fisheries are overexploited and also to facilitate sustainable fishing [1]. No-take marine pro-

\footnotetext{
*Corresponding author.
}

How to cite this paper: Islam, G.Md.N., Yew, T.S., Noh, K.M. and Noh, A.F.M. (2014) Community's Perspectives towards Marine Protected Area in Perhentian Marine Park, Malaysia. Open Journal of Marine Science, 4, 51-60. 
tected areas (MPAs) are areas of marine waters where fishing activities are prohibited [2] [3]. However, MPAs allow tourism activities, in order to enhance economic benefits while enabling the recovery of overexploited marine resources [4]-[8].

In Malaysia, the government had established MPAs in the 1980s. Malaysia has $3600 \mathrm{~km}^{2}$ of coral reef area. The coral reefs in Peninsular Malaysia are mostly protected as marine parks. The primary objectives of MPAs are to protect coral reef areas from fishing and other activities that may damage the ecosystem. Recently, rapid development has taken place in the tourism industry, and this sector accounts for the second largest foreign exchange earner in Malaysia. The islands in the east coast of Peninsular Malaysia have extensive and diverse coral reefs displaying 50\% - 70\% coral cover. A study conducted by Harborne et al. [9] recorded 221 hard coral species and 298 fish species around the marine park island along the east coast of Peninsular Malaysia.

In Peninsular Malaysia, a total of 42 marine parks have been gazetted, while 13 marine parks are located in Terengganu state in the east coast of Peninsular Malaysia. Perhentian is one of the coral reef islands in Terengganu State that has been gazetted as a Marine Park in 1994. A no-take MPA was established and fishing is totally restricted within two nautical miles from the shore. In Perhentian, majority of the local residents are fishers who mainly rely on fishing for their livelihoods.

The rich coral reef ecosystems and beautiful natural view of Perhentian Marine Park have attracted many visitors and massive development of tourism has taken place over the last ten years. Statistics on tourist arrivals showed an increasing trend, from 51,000 in 2004 to 90,000 in 2011 [10]. While tourism has become an important source of income for the local island residents, the increasing human pressure through tourism on the marine resources seems to be unsustainable in Perhentian. Wattage et al. [11] found that the major threat comes from human activity which has not been addressed in the assessment of MPAs. Most previous studies have found that about $85 \%$ of the Malaysian coral reefs are under medium to high levels of threat due to human activities in the coastal areas [12] [13]. Several studies have focused on the deterioration of coral reefs in Perhentian Island [9] [12].

Research on the role of marine protected areas in Malaysia in supporting the fisheries and tourism is limited. The contribution of MPA to fisheries resources and tourism has not been studied in detail in Malaysia. It is argued that despite the many potential benefits of MPAs to coastal management programs [14] the majority of MPAs failed to meet their management objectives due to the lack of effective monitoring, evaluation and adaptation [15]-[17]. Burke et al. [13] investigated management effectiveness of 332 MPAs in Southeast Asia. They found that only $14 \%$ of MPAs were effectively managed. The greatest extent of coral damage has occurred in Asia due to ineffective management [13] [18].

In this paper, we examine the local community perspectives toward conservation in the marine protected areas and the impacts of various activities taking place in Perhentian MPA. The results of the study will be useful for policy makers for effective planning and management of MPAs in Malaysia. This paper is organized as follows: Section 2 describes the general characteristics of Perhentian MPA and its current management status. Section 3 presents the method of paired comparison, questionnaire and data sources. Section 4 discusses the results, while the final section presents the discussions and policy recommendations for improving management of MPAs in Malaysia.

\section{Pulau Perhentian Marine Protected Area (PPMPA)}

The Pulau Perhentian (Perhentian Island) is located in the South China Sea, $21 \mathrm{~km}$ off the mainland of Terengganu State in the east coast of Peninsular Malaysia. The island is easily accessible by speedboat from the small fishing port of Kuala Besut on the mainland. The Perhentian Archipelago consists of two main islands, Perhentian Besar (large) and Perhentian Kecil (small), with approximately land areas of 867 and 524 hectares, respectively (Figure 1). There are also several smaller islands located close to the Perhentian Kecil. These islands are well known for their high quality coral reefs, variety of commercial fish species and beautiful sandy beaches.

With the diverse coral reef ecosystem and inter-tidal habitats, Pulau Perhentian is a breeding, nursing and feeding ground for numerous fish species, sea turtle and other resources. Tamblyn et al. [12] conducted a biological assessment of reefs and islands of Malaysia and recorded 127 types of fish species available in the marine waters surrounding the Pulau Perhentian. 


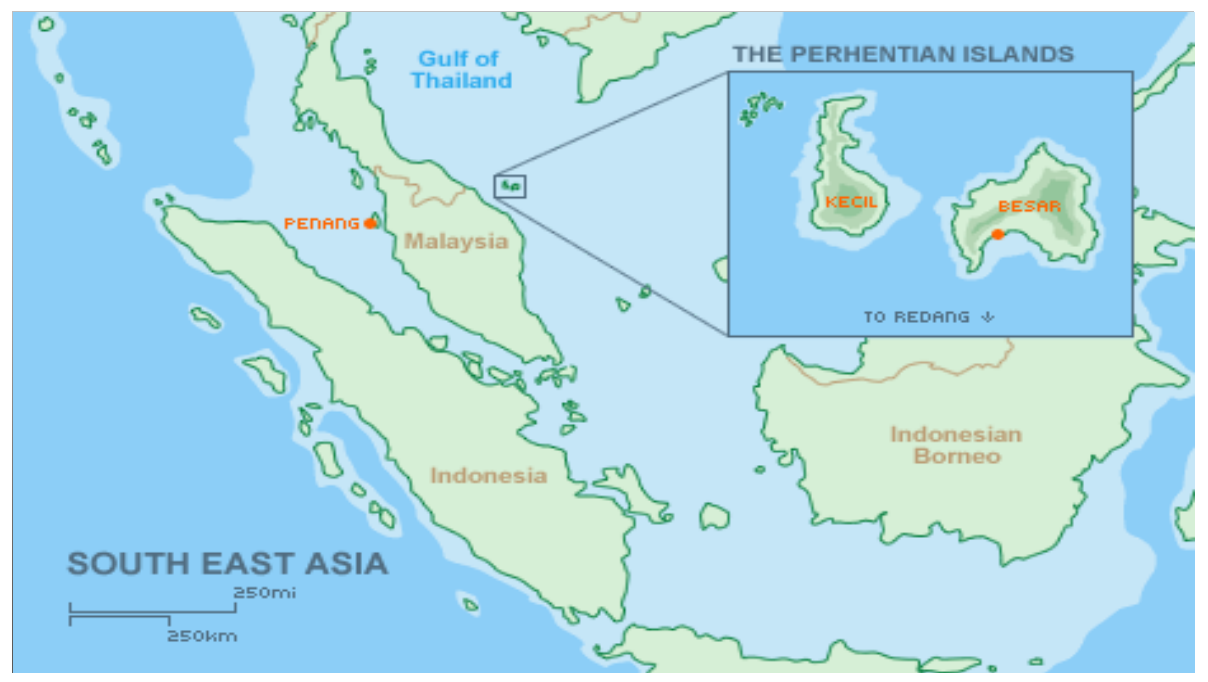

Figure 1. Perhentian Marine Protected Area.

Marine protected area in Pulau Perhentian was first initiated by the Department of Fisheries Malaysia (DoFM) in 1983. This island has been gazetted as a Marine Park in 1994 and then established no-take MPA where fishing was prohibited within two nautical miles from the lowest water level in the shore. Since 2004, the responsibility of MPA management has been transferred from DoFM to the Marine Park Department (DoMP) under the Ministry of Natural resources and Environment (MNRE). The main reason of these arrangements was to promote sustainable resource management and tourism in the marine parks. Management plans in the past had been formulated by the DoFM, and recently by DoMP, both agencies are under the Federal government jurisdiction. However, land in the island belongs to the State Government, who decides about the allocation of lands for various purposes. The dichotomy in jurisdiction between federal and state governments has been highlighted in several studies as serious constraints for successful marine resource management [19].

A massive physical infrastructural development has taken place in Pulau Perhentian over the last decade. These infrastructures consist of a jetty, a primary school, a health clinic, a police station and a post office. Electricity has become available through generators installed since 1994. Piped water is provided to the village from the water treatment plant on Perhentian besar. A number of resorts have been built both on Perhentian besar and Perhentian kecil. There are about 45 resorts/chalets, 19 dive shops, 40 souvenir shops, several restaurants and tea stalls employing a good number of local residents. The numbers of infrastructures are relatively higher compared to other marine pars in the east coast of Peninsular Malaysia.

There is a small village called Kampung Pasir Hantu of approximately 10 ha in area situated in Perhentian kecil (small sland). The village comprises of approximately 1200 residents, the majority of whom are Malays. Prior to the establishment of the Perhentian MPA, the majority of the local residents were fishers who rely mainly on the fishery resource for their livelihood.

Majority of the island inhabitants have moved to the tourism related activities which is available for 7 months (March-September) yearly. The island supports various recreational activities such as SCUBA diving, snorkeling, swimming and recreational fishing. This marine park is facing severe pressure from tourism activities. Pollution generally occurs from wastage discharges from chalets, littering on the beach, dumping of discarded fishing equipments, rubbish from restaurants, waste water from household, and boats anchoring on the coral reefs. Inadequate water and sanitation facilities also cause severe environmental problems on the beach in Perhentian MPA. However, the consequences of the human activities have not been given due consideration in the management of MPA in Perhentian Island.

Majority of the local people are involved in small scale fishing in Perhentian during the northeast monsoon season that occurs October to February. However, all tourism activities are closed during these five months. Fishers use small and relatively low powered boats with an average engine of 30 horsepower. They commonly use traditional fishing gear, namely hook and line, traps and gill/drift nets. During this season trawlers with relatively smaller boats operate at any distance from the coast. Fishers from other neighboring areas are also engaged in fishing close to the MPA area. 


\section{Paired Comparison and Damage Schedule Approach}

Damage schedule approach is a non monetary valuation approach where public judgments are elicited to assess the relative importance of resource losses [20]. This method was used to examine coastal development issues surrounding shrimp farming and tourism in Southern Thailand [21] [22]. Chuenpagdee et al. [20] applied this method to reveal local judgment on the severity of damages to coastal habitats and the impact of these activities in Mexico. Quah et al. [23] used this method to examine the environmental damage in urban coastal areas in Singapore. Chuenpagdee et al. [22] highlights that researchers prefer this method among the non-market resource valuation methods as this method is suitable and transparent.

It is important to seek public opinion about the MPAs in Perhentian and the impacts of various activities takes place that create pollution to the coral reefs and other marine resources in the MPA. This study provides information that can help to develop a management plan for MPA in Perhentian. Management policies which are based on the community preferences on the relative importance of a resource are likely to be effective. Scientists highlight on the community involvement for the success of a MPA [24]-[27]. Sumaila et al. [28] stated that involving the public in the early stage of planning and management of a MPA is one of the key factors leading to success in its implementation. Chuenpagdee et al. [29] suggests that a mechanism should be developed to involve local people in the management of MPA.

The survey method used in this study is similar to the 'damage schedule' method developed by Chuenpagdee [21] and Chuenpagdee et al. [22] to elicit public judgments on the relative importance of resource losses or the relative harmfulness of certain activities causing the losses in Perhentian MPA. A damage schedule is envisioned as a set of policy instruments similar to payments and sanctions that could be used to discourage damaging activities and compensate for resource losses.

In this approach a set of questions were used to express as a pairwise comparison to obtain an individual's opinion about the important activities damaging the resources. Similar to a discrete choice model, the paired comparison method presents two damage activity scenarios at a time. The method only compares between two objects or scenarios such as A and B in making subjective judgments by the respondents [30]. For each respondent, the total number of all possible pairs is $N(N-1) / 2$, where $N$ is the number of scenarios. For each pair, each respondents is asked to choose only one scenario (either $A$ or $B$ ) that they consider more important. Each of the important scenarios selected by an individual respondent is scored or aggregated across groups of respondents for further analysis [21]. These score values were then normalized to a scale of 0 (least importance) to 100 (most importance) using a proportional procedure [31]. A ranking was assigned to these normalized scores in order to test for an agreement between the respondent groups using the Kendall coefficient of agreement $(u)$ and Kendall Tau rank-order correlation analysis [32]. Kendall coefficient of agreement $(u)$ measures the degree of similarity of rank ordering provided by a single respondent group. The value of $u$ is one when there is total agreement among individuals. The scale values indicate the relative severity of the expected consequences of the activities. Thus, the important scale can be used to develop damage schedule.

The main advantages of using this method over traditional valuation methods is that it provides predictability and enforceability by specifying the payments in the event of a loss in advance, rather than wait until the damage has taken place. This method can guide policy makers in formulating policy design, regulatory control, management choice and payment for damages [22]. Chuenpagdee [21] and Chuenpagdee et al. [22] used similar "activity schedule” in their study and highlighted that this tool is more practical to guide different management policies. In this study therefore, a set of paired comparison questions were used to obtain opinions of various stakeholders from the community on the importance of different activities that cause resource losses in the Perhentian MPA.

\section{Questionnaire and Data Source}

In this study, two sets of paired comparison questions were used to obtain community's judgments about the importance of resources in Perhentian. The first set, seven activities were included that created pollution to the resources in the MPA, while in the second set, seven community programmes were included (Table 1) giving the total number of 21 pairs for each set.

These scenarios were chosen to represent existing and potential resource damages taking place within the MPA and community programmes that are relevant in Perhentian. This information was obtained during field visits and interviews with villagers and key informants. In first set, the respondents were asked to select one 
Table 1. Objects for each paired comparison set.

\begin{tabular}{ll}
\hline Set A: Description of activity scenarios & Set B: Community programmes \\
\hline - Too many people fishing in one area & - Establish artificial reefs for fishing \\
- Fishing in spawning area & - Provide technical training to the fishers \\
- Fishing using hook and line & - Provide micro credit \\
- Too many motorized boats for tourists & - Establish aquaculture in the sea \\
- Diving in the shallow part of the sea & - Ensure fishing access to inshore fisheries \\
- Littering on the beach & - Building residence for tourists \\
- Discarding fishing equipments & - Reduce the MPA area \\
\hline
\end{tabular}

resource damage activity from each pair that they considered more "severe" in terms of the impact on the marine resources in the MPA in Perhentian Island. In the second set, respondents were asked to choose one community programme that was likely to benefit to the community and promote conservation. In addition to the paired comparison questions, the questionnaire contained respondent's perceptions on the status of marine resource management in Perhentian MPA and their demographic characteristics, such as age, education, and income, was included in the questionnaire.

Respondents from the local village were divided into four subgroups, according to their current occupation, i.e., (1) fishers; (2) tourism operators such as tourist boat operators, tourist guides; (3) traders/shop owners; (4) local residents with other occupations such as teachers and housewives. The expert group mainly consists of government officials and university researchers and scientists in Terengganu who are familiar and have experience with the resource conditions in Perhentian MPA. Quota sampling was used to select minimum 30 respondents from each of the sub groups. A total of 128 respondents were selected for interviews from the five sub groups. The selected respondents were informed in advance about the interview with the assistance of the village leader and local enumerators. Interviews were mostly conducted in late afternoon as most of them were available during this time. The survey booklet was completed through face to face interview. A map and a set of pictures related to the resources and activities in the study area were provided to each respondent. Experts or resource persons were listed based on discussion with the officials from the Department of Fisheries, Southeast Asian Fisheries Development Centre (SEAFDEC) and Marine Park Department Malaysia (MPDM). Local enumerators visited each respondent and requested them to complete the questionnaire. The respondents had completed the questionnaires which were picked up a week later.

\section{Community Perspectives about Activities in MPA}

Of the 128 respondents, 107 were males, while 21 were females. Tourism workers and traders have relatively low average age (below 40 years) compared to fishers (48 years), experts (45 years). The average household size is six, ranged from 3 to 9 people. Majority of the tourism workers and traders had attained secondary education, while about half of the fishers had attained primary education.

Table 2 presents the Kendall's Tau rank-order correlation coefficients that express the degree of association between any two sets of scale values derived from the judgments of different groups of respondents (four local users groups and expert group). The coefficients obtained for the five respondent groups indicate close-to-perfect correlations (Table 2).

All the Kendall $T$ rank order correlation coefficients were significantly less than the $p$-value of 0.05 . This indicates that the levels of agreements were highly correlated among respondent groups, in both resource damage activities and community programmes.

Table 3 presents the aggregated performance score for the activity scenarios and community programmes based on the paired comparison for each of the five subgroups. These score values were then normalized ( 0 to $100)$ and a ranking was assigned to these normalized scores in order to test for an agreement between the respondent groups using Kendall coefficient of agreement $(u)$ and Kendall Tau rank-order correlation analysis [32]. Kendall coefficient of agreement $(u)$ measures the degree of similarity of rank ordering provided by a single respondent group. The value of $u$ is one when the level of agreement is full among individuals. The chi-square 
Table 2. Kendal Tau rank-order correlation coefficients.

\begin{tabular}{|c|c|c|c|c|c|}
\hline Group & Fishers & Tourism workers & Traders & Others & Experts \\
\hline \multicolumn{6}{|c|}{ Resource damage activities } \\
\hline Fishers & 1.000 & & & & \\
\hline Tourism & $0.964^{* *}$ & 1.000 & & & \\
\hline Traders & $0.964^{* *}$ & $1.000^{* *}$ & 1.000 & & \\
\hline Others & $0.929^{* *}$ & $0.964^{* *}$ & $0.964^{* *}$ & 1.000 & \\
\hline Experts & $0.752^{*}$ & $0.857^{* *}$ & $0.857^{* *}$ & $0.786^{*}$ & 1.000 \\
\hline \multicolumn{6}{|c|}{ Community Programmes } \\
\hline Fishers & 1.000 & & & & \\
\hline Tourism & $0.881^{* *}$ & 1.000 & & & \\
\hline Traders & $0.821^{* *}$ & $0.992^{* *}$ & 1.000 & & \\
\hline Others & 0.672 & $0.870^{* *}$ & $0.871^{* *}$ & 1.000 & \\
\hline Experts & $0.909^{* *}$ & $0.988^{* *}$ & $0.975^{* *}$ & $0.821^{* *}$ & 1.000 \\
\hline
\end{tabular}

${ }^{* *}$ Denotes significant correlation at $p=0.01$; ${ }^{*}$ Denotes significant correlation at $p=0.05$.

Table 3. Aggregated performance scores for the activities and programmes by groups.

\begin{tabular}{|c|c|c|c|c|c|}
\hline Damage activity and community programmes & Fishers & Tourism & Traders & Others & Experts \\
\hline \multicolumn{6}{|c|}{ Resource damage activities } \\
\hline Littering on the shore & $75(1)$ & $85(1)$ & $83(1)$ & $87(2)$ & $93(1)$ \\
\hline Discarded fishing equipments & $72(2)$ & $81(2)$ & $73(2)$ & $88(1)$ & $58(3)$ \\
\hline Fishing in spawning area & $65(3)$ & $60(3)$ & $55(3)$ & $45(3)$ & $72(2)$ \\
\hline Too many people fishing & $32(5)$ & $48(4)$ & $44(4)$ & $43(4)$ & $55(4)$ \\
\hline Diving in the shallow part of MPA & $58(4)$ & $30(5)$ & $29(5)$ & $29(5)$ & $20(7)$ \\
\hline Too many motorized boats & $19(6)$ & $14(6)$ & $23(6)$ & $24(6)$ & $29(5)$ \\
\hline Fishing using hooks and line & $12(7)$ & $13(7)$ & $16(7)$ & $18(7)$ & $19(6)$ \\
\hline Number of respondents $k$ & 30 & 32 & 29 & 14 & 23 \\
\hline Kendall coefficient of agreement u & 0.448 & 0.496 & 0.352 & 0.304 & 0.315 \\
\hline Chi-square $^{*}$ & 293.6 & 343.9 & 227.8 & 104.0 & 166.5 \\
\hline \multicolumn{6}{|c|}{ Community programmes } \\
\hline Establish artificial reefs for fishing & $77(1)$ & $71(1)$ & $62(1)$ & $61(3)$ & $83(1)$ \\
\hline Provide technical training to the fishers & $59(2)$ & $70(2)$ & $61(2)$ & $85(2)$ & $71(2)$ \\
\hline Provide micro credit & $54(3)$ & $68(3)$ & $59(3)$ & $76(1)$ & $64(3)$ \\
\hline Establish aquaculture in the sea & $52(4)$ & $48(4)$ & $51(4)$ & $43(5)$ & $46(4)$ \\
\hline Fishing access to inshore fisheries & $31(6)$ & $31(5)$ & $34(6)$ & $36(6)$ & $36(6)$ \\
\hline Building residence for tourists & $31(6)$ & $39(5)$ & $42(5)$ & $48(4)$ & $43(5)$ \\
\hline Reduce the MPA area & $44(5)$ & $22(7)$ & $27(7)$ & $23(7)$ & $23(7)$ \\
\hline Number of respondents & 30 & 32 & 29 & 14 & 23 \\
\hline Kendall coefficient of agreement u & 0.370 & 0.469 & 0.551 & 0.314 & 0.224 \\
\hline Chi-square $^{*}$ & 168.8 & 208.0 & 247.2 & 138.6 & 153.2 \\
\hline
\end{tabular}

*Significant agreement at $p<0.001$. Note: Figures in parenthesis show rankings. 
goodness-of-fit test was used to test the significance of agreement for a large sample size. The chi-square goodness-of-fit tests for Kendall coefficient of agreement (u) are all less than the critical $p$-value of 0.001 . The results indicate that there was significant agreement among the respondents in each subgroup (Table 3).

The study found that both resource dependent groups and expert group had similar concerns about damaging activities and they have preferred similar community programmes in Perhentian MPA. Therefore, it was possible to aggregate the scores of all respondents into one scale for damaging activities and another scale for community programmes presented in Table 4.

Among the activities, littering was the most damaging activity (scale value of 85), followed by discarded fishing equipments in the MPA (scale value of 74). The preference score obtained from resource dependent groups and expert group shows that they are concerned about littering and discarded fishing equipment as most damaging to the resources in MPA. The range between these two activities was small for the resource dependent groups but the range was large for the expert group (58 to 93). These suggest that the experts are not aware of the problem of discarding fishing materials, although they are concerned about unauthorized fishing (scale value of 72) in the spawning area in the MPA (Table 3). The range of other activities such as too many people fish, diving, use of motorized boats, and fishing by hooks was small (14 to 55). The low range of these activities is mainly because these activities are associated with either fishing or tourism activities.

In the community programmes, it was found that fishers mostly preferred the activities that might increase fish productivity (scale value of 77) for example increase fish biomass through artificial reef establishment, while other groups (women and traders) preferred micro credit programme. They need micro credit to invest in various self employment activities to increase their income. The disparity between fishers and other groups in terms of their preferred programmes is mainly because the fishers heavily rely on fishing for their livelihoods while the women members are now getting self employment opportunities in grocery shop, tea stall and restaurant. The aggregated score and ranking show that littering, discarded fishing equipment in the shore area and fishing were the most damaging activities in Perhentian MPA while establishing artificial reefs surrounding the MPA areas was suggested to be a conservation oriented programme in Perhentian (Table 4). The main source of littering is the excessive tourism pressure on Perhentian. Many visitors stay in the chalets on the small island have created excessive pressure on the resources that generate pollution. It reveals that although tourism contributes positively to the local economy, its adverse impacts on the resources are crucial for sustainability of marine resources. The degradation of marine resources will, in the long term, significantly affect the livelihoods of the local people who are dependent on the resources.

\section{Policy and Management Implications}

In this study, we investigate whether human activities in the Perhentian MPA contribute negative impacts on the environment and economy. Damage schedule method is used to elicit community judgments regarding the activities that negatively affect the marine resources in the MPA. The result of the study shows that all the sub groups of respondents are concerned about degradation of marine resources especially the coral reefs and its associated resources in Perhentian MPA. The findings of the study provide useful information that should be incorporated in planning and management of MPA to ensure sustainable use of marine resources in Perhentian MPA.

Table 4. Aggregated performance scores.

\begin{tabular}{|c|c|c|c|}
\hline Resource Damage Activities & All groups & Community Programme & All groups \\
\hline Littering on the shore & $85(1)$ & Creating an artificial habitat outside MPA & $71(1)$ \\
\hline Discarded fishing equipments & $74(2)$ & Build a centre for technical training & $69(2)$ \\
\hline Fishing in spawning area & $59(3)$ & Provide micro credit support & $64(3)$ \\
\hline Too many people fishing & $44(4)$ & Promote small scale aquaculture & $48(4)$ \\
\hline Diving in the shallow part of MPA & $33(5)$ & Build hotels/chalet for tourists & $41(5)$ \\
\hline Too many motorized boats & $22(6)$ & Provide fishing access for local fishers & $34(6)$ \\
\hline Fishing using hooks and line & $16(7)$ & Reducing the restricted area of MPA & $28(7)$ \\
\hline
\end{tabular}


The main objective of establishing MPAs was to enhance fisheries and tourism activities through conserving marine resources in Perhentian. The current tourism management in Perhentian should be examined in order to determine how the tourism activities affect negatively to the coral reef and fisheries habitats in the MPA area. Although fishing activities were totally banned in the MPA, the tourism activities are mostly driven by economic benefits in Perhentian. Many tourists visit this island and they undertake high impact tourism activities such as diving and snorkeling. If this practice continues the coral reefs will be further degraded. The government should impose restrictions on the important activities that directly damage the coral reefs. The predetermined damage schedule developed based on the community perceptions can be used as a guide to adjust the MPA management policy to protect the coral reefs and fisheries.

The study suggests that the coral reefs in Perhentian Island are under serious threat. Sustainability of tourism in this island directly depends on the health of coral reefs. However, the overwhelming pressure from the tourism activities on the small island results in serious congestion. Studies on MPAs highlighted that small island destinations are the most vulnerable to environmental impacts from tourism activities [33]. Salmond [34] found that land based development activities have created significant damage to the coral reef habitats in Perhentian Island. However, the environmental consequences of tourism in the marine parks have not been addressed in the design and implementation of marine policies in Malaysia. There is a need to conduct Environmental Impact Assessment (EIA) to assess the possible risk and threats from human activities on the marine resources in the MPA.

The evidence clearly indicates that majority of the local fishers are involved in small scale fishing activities surrounding the MPA area during the monsoon season (October-February). Although fishing is totally prohibited in the MPA area in Perhentian, encroachment of commercial fishing, such as trawl nets, is taking place surrounding the MPA areas during monsoon season. Local fishers are not able to protect fishing by outsiders. Some illegal fishers discard their fishing equipments in the sea to escape marine rangers. These generally hamper diving activities as well as pollute the coral reef habitats in Perhentian. The legal issues in fisheries management need to be addressed carefully by the line agencies such as the Department of Fisheries and the Department of Marine Park.

In spite of total fishing ban in the MPA area, a multiple use mechanism should be developed to allow fishers to fish for their subsistence need since they have been using this resource for generations for their livelihoods. One of the main constraints for successful MPA management is that lack of consultation with local residents prior to construction of MPA development activities in the marine parks. The top down management system in Malaysia generally excludes local people from the management of marine resource. These institutional and legal issues can be resolved through a series of meetings and workshops with multiple stakeholders at local level. Fisheries management would be effective if local fishing communities are agreed to be co-responsible for conservation and other harvesting control activities in MPA areas.

In Malaysia, the important issue with the management of MPA arises due to lack of coordination between the federal and state governments. The state government has control over land matters on the marine park islands while the Marine Park Department Malaysia (MPDM) is responsible for management of MPAs particularly the jurisdiction of water area up to two nautical miles surrounding the island. These overlapping jurisdictions of legislation between state and federal governments are the major constraint for sustainable marine park management in Perhentian MPA. Both the state and federal governments have an important role to play in planning, zoning and regulating the MPA management. The government should prohibit land based development activities on the islands which is a direct threat to the health of the coral reef ecosystems. Both state and federal agencies should give priority to involve community which is a key factor in ensuring the success of a marine protected area [24]-[27]. Sumaila et al. [28] highlighted that successful implementation of MPA management is difficult without consultation with local people.

The results of the study reveal that there is a good understanding on the resource importance and public concerns about their critical conditions in Perhentian. Public awareness and education programs on the importance of the coral reef ecosystem should be provided to the local people who are the main users of the resources. Besides, marine park staff, tour operators, dive operators should also be adequately trained to reduce harmful activities and ensure sustainable management of MPAs in Malaysia.

\section{Acknowledgements}

The authors are grateful for financial support provided by the Research University Grants (RUGS), Universiti 
Putra Malaysia. The authors gratefully acknowledge the field support and assistance provided by the SEAFDEC/ MFRDMD team in Terengganu. Lastly, we are grateful to all the respondents who participated in our study.

\section{References}

[1] Alban, F. and Boncoeur, J. (2006) Assessing the Impact of Marine Protected Areas on Recreational Uses of a Marine Ecosystem: The Case of Scuba Diving. In: Proceedings of the IFFET Conference, IFFET, Portsmouth, 8p.

[2] Roberts, C.M. and Hawkins, J.P. (2000) Fully Protected Marine Reserves: A Guide. Endangered Seas Campaign. World Wildlife Fund, Washington DC and University of York, York.

[3] Gell, F. and Roberts, C. (2000) Benefits beyond Boundaries: The Fishery effects of marine Reserves and Fishery Closures. WWF-US, Washington DC.

[4] Kelleher, G., Bleakley, C. and Wells, S. (1995) A Global Representative System of Marine Protected Areas. World Bank, Washington DC.

[5] Lauck, T., Clark, C., Mangel, M. and Munro, G. (1998) Implementing the Precautionary Principle in Fisheries Management through Marine Protected Areas. Ecological Applications, 8, s72-s78. http://dx.doi.org/10.2307/2641364

[6] Guénette, S. and Pitcher, T.J. (1999) An Age-Structured Model Showing the Benefits of Marine Reserves against Overexploitation. Fisheries Research, 39, 295-303. http://dx.doi.org/10.1016/S0165-7836(98)00173-8

[7] Russ, G.R. and Alcala, A.C. (2003) Marine Reserves: Rates and Patterns of Recovery and Decline of Predatory Fish 1983-2000. Ecological Applications, 13, 1553-1565. http://dx.doi.org/10.1890/01-5341

[8] Gaylord, B., Gaines, S.D., Siegel, D.A. and Carr, M.H. (2005) Marine Reserves Exploit Population Structure and Life History in Potentially Improving Fishery Yields. Ecological Applications, 15, 2180-2191. http://dx.doi.org/10.1890/04-1810

[9] Harborne, A., Fenner, D., Bames, A., Beger, M., Harding, S. and Roxburgh, T. (2000) Status Report on Coral Reefs of the East Coast of Peninsular Malaysia, Kuala Lumpur. Department of Fisheries Malaysia, Sabah.

[10] Department of Marine Park (2012) Visitors in Perhentian Island. Department of Marine Park Office, Terengganu. (unpublished data)

[11] Wattage, P., Glenn, H., Mardle, S., Van Rensburg, T., Grehan, A. and Foley, N. (2011) Economic Value of Conserving Deep-Sea Corals in Irish Waters: A Choice Experiment Study on Marine Protected Areas. Fisheries Research, 107, 5967. http://dx.doi.org/10.1016/j.fishres.2010.10.007

[12] Tamblyn, A., Turner, C., O’Malley, R., Weaver, N., Hughes, T., Hardingham, S. and Roberts, H. (2005) Malaysia Tropical Forest Conservation Project, Report of the Perhentian Island. Coral Cay Conservation Ltd., London, SW19 2JG.

[13] Burke, L., Selig, L. and Spalding, M. (2002) Reefs at Risk in Southeast Asia. World Resources Institute, Washington DC.

[14] Halpern, B. (2003) The Impact of Marine Reserves: Do Reserves Work and Does Reserve Size Matter? Ecological Applications, 13, 117-137. http://dx.doi.org/10.1890/1051-0761(2003)013[0117:TIOMRD]2.0.CO;2

[15] Day, J. (2008) The Need and Practice of Monitoring, Evaluating and Adapting Marine Planning and Management E-Lessons from the Great Barrier Reef. Marine Policy, 32, 823-831. http://dx.doi.org/10.1016/j.marpol.2008.03.023

[16] Mora, C., Andrefouet, S., Costello, M.J., Kranenburg, C., Rollo, A., Veron, J., Gaston, K.J. and Myers, R.A. (2006) Coral Reefs and the Global Network of Marine Protected Areas. Science, 312, 1750-1751. http://dx.doi.org/10.1126/science.1125295

[17] Jameson, S.C., Tupper, M.H. and Ridley, J.M. (2002) The Three Screen Doors: Can Marine "Protected” Areas be Effective? Marine Pollution Bulletin, 44, 1177-1183. http://dx.doi.org/10.1016/S0025-326X(02)00258-8

[18] Tun, K., Chou, L.M., Cabanban, A. and Tuan, V.S. (2004) "Status of Coral Reefs,” Coral Reef Monitoring and Management in Southeast Asia. In: Wilkinson, C., Ed., Status of Coral Reefs of the World, Australian Institute of Marine Science, Queensland, 235-275.

[19] Gopinath, N. and Puvanesuri, S.S. (2006) Marine Capture Fisheries. Aquatic Ecosystem Health \& Management, 9, 215-226. http://dx.doi.org/10.1080/14634980600721086

[20] Chuenpagdee, R., Fraga, J. and Euan, J. (2002) Community’s Perspective toward Marine Reserve: A Case Study of San Felipe, Yucatan, Mexico. Coastal Management, 30, 183-191. http://dx.doi.org/10.1080/089207502753504706

[21] Chuenpagdee, R. (1998) Damage Schedules for Thai Coastal Areas: An Alternative Approach to Assessing Environmental Values. EEPSEA Research Report Series, Singapore.

[22] Chuenpagdee, R., Knetsch, J.L. and Brown, T.C. (2001) Environmental Damage Schedules: Community Judgments of 
Importance and Assessments of Losses. Land Economics, 77, 1-11. http://dx.doi.org/10.2307/3146976

[23] Quah, E., Choa, E. and Tan, K.C. (2006) Use of Damage Schedules in Environmental Valuation: The Case of Urban Singapore. Applied Economics, 38, 1501-1512. http://dx.doi.org/10.1080/00036840500399842

[24] White, A.T. (1986) Marine Reserves: How Effective as Management Strategies for Philippines, Indonesian and Malaysian Coral Reef Environments? Ocean Management, 10, 137-159. http://dx.doi.org/10.1016/0302-184X(86)90019-3

[25] Kaza, S. (1988) Community Involvement in Marine Protected Areas. Oceans, 31, 75-81.

[26] Kenchington, R.A. (1988) Managing Reefs and Inter-Reef Environments and Resources for Sustained Exploitive, Extractive and Recreational Uses. Proceedings of the 6th International Coral Reef Symposium, 1, 81-87.

[27] Cinner, J. (2005) Socioeconomic Factors Influencing Customary Marine Tenure in the Indo-Pacific. Ecology and Society, 10, 1-14.

[28] Sumaila, U.R., Guennette, S., Alder, J. and Chuenpagdee, R. (2000) Addressing Ecosystem Effects of Fishing Using Marine Protected Areas. ICES Journal of Marine Science, 57, 752-760. http://dx.doi.org/10.1006/jmsc.2000.0732

[29] Chuenpagdee, R., Julia, F., Ricardo, T. and Jorge, E. (2001) Importance of Marine Protected Areas and their Benefits: the Local Community's Perspectives. In: R. Sumaila, Eds., Economic of Marine Protected Areas, Fisheries Center Research Reports, Fisheries Centre, University of British Columbia, Canada, The Fisheries Centre, University of British Columbia, Vancouver.

[30] David, H.A. (1988) The Method of Paired Comparisons. Charles Griffin \& Company, London.

[31] Dunn-Rankin, R. (1983) Scaling Methods. Lawrence Erlbaum Associates, New Jersey.

[32] Siegel, S. and Castellan, N.J. (1988) Nonparametric Statistics for the Behavioral Sciences. 2nd Edition, McGraw-Hill, New York.

[33] Gossling, S. (2003) Tourism and Development in Tropical Islands: Political Ecology Perspectives. Edward Elgar Publishing Ltd., Cheltenham.

[34] Salmond, L.J. (2010) The Social Relations of Tourism on the Perhentian Islamds. Doctoral Dissertations, University of Kentucky, Lexington. http://uknowledge.uky.edu/gradschool_diss/2 